\title{
PENGARUH MOTIVASI, KOMUNIKASI, DAN LINGKUNGAN KERJA FISIK TERHADAP SEMANGAT KERJA KARYAWAN PT. AYU SARI PERTIWI
}

\author{
Ni Putu Intan Cahya Dewi ${ }^{1}$ \\ A.A. Sagung Kartika Dewi \\ ${ }^{1,2}$ Fakultas Ekonomi dan Bisnis Universitas Udayana (Unud), Bali, Indonesia \\ email: intancahyadewi@ymail.com
}

\begin{abstract}
ABSTRAK
Semangat kerja adalah gairah seseorang dalam melaksanakan pekerjaan dengan giat dan dapat terselesaikan tepat waktu. Tidak tersedianya penjagaan kesehatan untuk karyawan, komunikasi yang tidak lancar antara karyawan dan atasannya, dan keadaan suhu udara dan kebisingan di lingkungan kerja akan mengurangi tingkat semangat kerja karyawan. Penelitian ini bertujuan untuk mengetahui pengaruh signifikan dari motivasi, komunikasi, dan lingkungan kerja fisik terhadap semangat kerja karyawan PT. Ayu Sari Pertiwi. Jumlah responden sebanyak 56 karyawan. Pengumpulan data menggunakan metode wawancara dan metode kuesioner. Teknik analisis data yang digunakan adalah analisis regresi linier berganda. Berdasarkan hasil analisis ditemukan bahwa motivasi, komunikasi dan lingkungan kerja fisik berpengaruh positif dan signifikan terhadap semangat kerja. Hasil penelitian ini mengimplikasikan bahwa semakin termotivasi karyawan terhadap pekerjaannya maka semangat kerjanya juga tinggi, komunikasii yang terjalin dengan baik dapat meningkatkan semangat kerja, dan lingkungan kerja yang baik dapat meningkatkan semangat kerja.
\end{abstract}

Kata kunci : semangat kerja, motivasi, komunikasi, dan lingkungan kerja fisik

\section{ABSTRACT}

Work morale is someone's passion in carrying out work diligently and can be completed on time. Unavailability of health care for employees, communication between employees and superiors, and conditions of air temperature and noise in the work environment will reduce the level of employee morale. This study aims to determine the significant effect of motivation, communication, and physical work environment on employee morale of PT. Ayu Sari Pertiwi. The number of respondents is 56 employees. Data collection using interview methods and questionnaire methods. Multiple linear regression analysis was used.. Based on the results of the analysis it was found that motivation, communication and physical work environment had a positive and significant effect on work morale. The results of this study imply that the more motivated employees are towards their work, the work enthusiasm is also high, good communication can increase morale, and a good work environment can increase morale. Keywords: work morale, motivation, communication, and physical work environment 


\section{PENDAHULUAN}

Saat ini dengan perkembangan ekonomi yang sangat pesat menuntut para pengusaha untuk meningkatkan standar yang lebih tinggi terhadap pelayanan suatu organisasi. Untuk mencapai pelayanan yang maksimal perusahaan perlu memperhatikan peran sumber daya manusia didalamnya. Sumber daya manusia memegang peranan yang penting didalam seuah perusahaan karena berkaitan langsung dengan pelaksanaan kegiatan dalam perusahaan. Menciptakan sumber daya manusia yang optimal perlu mendapat perhatian untuk membantu perusahaan dalam mencapai tujuannya. Memperhatikan serta menciptakan semangat kerja karyawan didalam perusahaan merupakan salah satu yang dapat dilakukan oleh perusahaan.

Semangat kerja merupakan kegiatan melakukan pekerjaan secara lebih giat, dengan hal tersebut diharapkan apapun pekerjaan yang dilakukan dapat lebih cepat diselesaikan dan akhirnya akan memperoleh hasil yang memuaskan (Nitisemito, 2008:96). Jika semangat kerja yang ada di dalam diri seorang karyawan rendah maka karyawan tersebut akan bekerja sesuai dengan apa yang diperintahkan oleh atasannya saja. Sedangkan apabila seorang karyawan memiliki semangat kerja yang tinggi maka karyawan tersebut akan bekerja dengan antusias akan berpartisipasi dan dengan penuh komitmen mengerjakan tugas dan tanggung jawabnya.

PT. Ayu Sari Pertiwi merupakan perusahaan yang bergerak di bidang perdagangan yaitu penjualan bahan bakar kendaraan umum (SPBU) dengan nomor 541.801.2. PT. Ayu Sari Pertiwi memiliki 2 stasiun yang keduanya berlokasi di Kota Denpasar yaitu di Jalan Imam Bonjol, Kecamatan Denpasar barat dan di Jalan Raya Sesetan, Kecamatan Denpasar Selatan. Berdasarkan observasi dan informasi awal yang di dapatkan dengan melakukan pra-survey melalui kuisioner tentang semangat kerja karyawan kepada 10 orang karyawan PT. Ayu Sari Pertiwi didapatkan data sebagai berikut:

Tabel 1.

Data Semangat Kerja Karyawan PT. Ayu Sari Pertiwi Tahun 2018

\begin{tabular}{clccccc}
\hline No & \multicolumn{1}{c}{ Daftar Pernyataan } & STS & TS & N & S & SS \\
\hline 1 & $\begin{array}{l}\text { Tingkat kehadiran saya sudah baik } \\
\text { Pekerjaan yang saya lakukan selesai tepat } \\
\text { waktu }\end{array}$ & 3 & 3 & 2 & 1 & 1 \\
3 & $\begin{array}{l}\text { Saya tidak meninggalkan pekerjaan saat jam } \\
\text { kerja }\end{array}$ & 3 & 4 & 2 & 1 & 0 \\
4 & $\begin{array}{l}\text { Saya melaksanakan pekerjaan sesuai dengan } \\
\text { instruksi atasan }\end{array}$ & 1 & 4 & 2 & 3 & 0 \\
5 & $\begin{array}{l}\text { Saya puas dengan pembagian kerja yang } \\
\text { dilakukan }\end{array}$ & 2 & 3 & 2 & 2 & 1 \\
$\quad$ Total Jawaban & 10 & 20 & 11 & 7 & 2 \\
\hline
\end{tabular}

Sumber : Data primer diolah, 2018

Tabel 1. menunjukkan pernyataan yang berkaitan dengan semangat kerja. Berdasarkan Tabel 1. terlihat bahwa distribusi skor tertinggi ada pada skor 2 (tidak setuju) sejumlah 20 jawaban dengan jumlah tertinggi diperoleh oleh pernyataan bahwa "tingkat kehadiran saya sudah baik" sebanyak 6 jawaban. Hal tersebut menunjukkan bahwa adanya masalah kehadiran oleh beberapa karyawan PT. Ayu 
Sari Pertiwi. Tabel 1. juga menunjukkan bahwa total jawaban sangat tidak setuju sebesar 10 jawaban dengan total jawaban tertinggi ada pada pernyataan "pekerjaan yang saya lakukan selesai tepat waktu dan saya tidak meninggalkan pekerjaan saat jam kerja" masing-masing sebanyak 3 jawaban. Hal ini berarti terdapat indikasi kurangnya semangat para karyawan PT. Ayu Sari Pertiwi. Semangat kerja karyawan merupakan hal penting yang harus diperhatikan organisasi dalam mempertahankan keefektifan organisasi tersebut (Alwi dkk., 2016).

Nitisemito (2008:13) menyatakan faktor-faktor yang dapat meningkatkan semangat kerja karyawan meliputi kepemimpinan, motivasi, komunikasi, hubungan manusia, partisipasi, lingkungan fisik, dan kompensasi. Berdasarkan observasi lebih lanjut dengan wawancara didapatkan informasi bahwa kurangnya semangat kerja pada karyawan PT. Ayu Sari Pertiwi dipengaruhi oleh beberapa variabel yang dominan meliputi motivasi, komunikasi, dan lingkungan kerja fisik. Utamajaya \& Sriathi (2015) menyatakan bahwa motivasi, komunikasi, dan lingkungan kerja fisik berpengaruh terhadap semangat kerja karyawan dalam penelitiannya yang dilakukan di Fuji Jaya Motor Gianyar.

Motivasi merupakan salah satu variabel yang mempengaruhi semangat kerja. Berdasarkan wawancara yang telah dilakuakan pada perusahaan PT. Ayu Sari Pertiwi terdapat masalah yang berkaitan dengan rendahnya semangat kerja para karyawannya. Permasalahan tersebut disebabkan oleh beberapa hal yang menyangkut kurangnya motivasi yang diberikan berupa penjagaan kesehatan yang tidak tersedia dan kurangnya dorongan dari pemimpin dalam memberikan penghargaan pada setiap pencapaian karyawannya sehingga semangat kerja karyawan menjadi sangat rendah yang mengakibatkan karyawan sering meninggalkan pekerjaannya saat sedang tidak diawasi secara langsung oleh manajernya. Irawan et al. (2018) menyatakan bahwa untuk meningkatkan semangat kerja dan kepuasan kerja, pemimpin perusahaan harus memberikan karyawan motivasi.

Tella (2007) menyatakan motivasi yang efektif dan kuat di berbagai tingkat akan membuat karyawan merasa puas dalam pekerjaannya. Menurut Aborisade \& Obioha (2009) menyatakan motivasi adalah dorongan psikologis untuk mengarahkan seseorang menuju motivasi yang melibatkan gerakan fisik dan mental. Ahmed et al. (2010) menyatakan motivasi merupakan suatu dorongan dan kekuatan agar melakukan sesuatu yang mengarahkan perilaku.

Komunikasi juga merupakan variabel yang mempengaruhi semangat kerja karyawan. Berdasarkan observasi awal yang dilakukan pada karyawan PT. Ayu Sari Pertiwi didapatkan informasi bahwa mereka memiliki atasan yang cenderung kaku sehingga para karyawannya merasa takut dalam mengutarakan pendapatnya. Selain itu sering pula terjadi masalah komunikasi antara satu karyawan dengan karyawan yang lainnya dalam hal pembagian jadwal jam kerja yang menyebabkan hubungan yang tidak baik antara karyawan tersebut. Komunikasi yang tidak lancar atau tidak baik antara atasan dengan karyawannya ataupun antara sesama karyawan akan berpengaruh terhadap semangat kerja karyawan.

Penelitian Utamajaya \& Sriathi (2015) mengatakan bahwa komunikasi berpengaruh terhadap semangat kerja karyawan. Semangat kerja yang tinggi dapat didukung oleh komunikasi yang baik, bagaimana karyawan berinteraksi, 
menyampaikan informasi, bertukar gagasan, baik antara atasan ke bawahan maupun sebaliknya. Rochim (2011) menunjukkan bahwa komunikasi berpengaruh signifikan terhadap semangat kerja, hal ini berarti bahwa semakin intens dan intern komunikasi yang dilakukan maka akan semakin meningkatkan semangat kerja.

Lingkungan kerja fisik juga merupakan variabel yang mempengaruhi semangat kerja karyawan dimana para karyawan PT. Ayu Sari Pertiwi merasa terganggu oleh polusi yang disebabkan oleh emisi gas buang kendaraan yang mengancam kesehatan mereka. Ratnasari \& Sudjahjo (2017) menyatakan bahwa lingkungan kerja fisik berpengaruh signifikan terhadap semangat kerja. Lingkungan kerja yang baik akan berdampak langsung terhadap hasil kerja karyawan.

Hasanah (2016) menyatakan lingkungan kerja yang baik dan mendukung dapat meningkatkan semangat kerja karyawan, karena dengan adanya lingkungan serta fasilitas yang lengkap dan mendorong karyawan untuk melaksanakan tugasnya dengan baik, merasa senang dan tidak malas, sehingga memacu semangat kerja karyawan untuk melaksanakan pekerjaannya. Penelitian ini meneliti mengenai pengaruh motivasi, komunikasi, dan lingkungan kerja fisik terhadap semangat kerja karyawan PT. Ayu Sari Pertiwi.

Berdasarkan latar belakang diatas, terdapat pembahasan dalam penelitian ini yang dapat dirumuskan sebagai berikut: 1) Bagaimana pengaruh motivasi terhadap semangat kerja karyawan? 2) Bagaimana pengaruh komunikasi terhadap semangat kerja karyawan? 3) Bagaimana pengaruh lingkungan kerja fisik terhadap semangat kerja karyawan?.

Berdasarkan latar belakang diatas serta rumusan masalah yang telah dijabarkan, maka terdapat tujuan penelitian ini adalah: 1) Untuk mengetahui dan menjelaskan pengaruh motivasi terhadap semangat kerja karyawan. 2) Untuk mengetahui dan menjelaskan pengaruh komunikasi terhadap semangat kerja karyawan. 3) Untuk mengetahui dan menjelaskan pengaruh lingkungan kerja fisik terhadap semangat kerja karyawan.

Penelitian ini diharapkan mampu menjadi tambahan referensi baru dan menjadi kontribusi di bidang ilmu manajemen SDM terkait pengaruh dari motivasi, komunikasi, dan lingkungan kerja fisik terhadap semangat kerja karyawan.

Hasil penelitian ini dapat digunakan sebagai bahan informasi dalam pertimbangan pengambilan kebijakan terhadap karyawan dan sebagai masukan bagi pihak manajemen PT. Ayu Sari Pertiwidalam pengembangan sumber daya manusianya dalam upaya pencapaian efektifitas karyawannya.

Teori yang digunakan dalam penelitian ini adalah teori motivasi dua faktor oleh Frederick Herzberg ini menjelaskan bahwa terdapat dua faktor yaitu intrinsik dan ekstrinsik yang mempengaruhi seseorang dalam bekerja. Faktor intrinsik adalah (motivator) merupakan faktor yang kehadirannya dapat menimbulkan rasa gairah atau semangat karyawan dalam melakukan tugasnya sehingga dapat meningkatkan hasil kerja. Yang termasuk faktor ekstrinsik adalah (higienies), dalam penelitian ini hubungan interpersonal antara atasan dan bawahan dapat dilihat dari komunkasi yang terjalin antara sesama karyawan ataupun antara karyawan dengan atasannya. Selain hubungan interpersonal, kondisi pekejaan juga dapat dilihat dari penjagaan kesehatan dan fasilitas-fasilitas yang diberikan 
perusahaan. Hal ini berkaitan dengan komunikasi dan lingkungan kerja para karyawan yang berdampak pada semangat kerja karyawan. Tanpa adanya kedua faktor ini dapat menimbulkan turunnya rasa gairahan karyawan dalam bekerja dana akan mempengaruhi tingkat kehadiran karyawan.

Motivasi merupakan dorongan untuk memenuhi sebuah tujuan tertentu yang ditandai dengan sebuah tindakan dimana motivasi merupakan proses mengarahkan perilaku dan kinerja. Motivasi sangat dibutuhkan di dalam sebuah organisasi dalam meningkatkan semangat kerja para karyawannya. Terdapat penelitian terdahulu mengenai hubungan antara motivasi terhadap semangat kerja yang menyatakan bahwa terdapat hubungan positif diantara keduanya. Motivasi merupakan aspek penting dalam mendorong karyawan untuk mencapai kinerja yang optimal. Motivasi bisa berasal dari diri sendiri ataupun dari dukungan yang diberikan oleh orang lain. Omolo (2015) menyatakan bahwa motivasi berpengaruh terhadap semangat kerja, motivasi dapat memperbaiki semangat dalam bekerja. Apabila motivasi baik maka semangat kerja akan meningkat, begitu pula apabila motivasi tidak baik maka semangat kerja akan menurun (Yahyo \& Dewi, 2013).

Hasan \& Subhani (2011) menyatakan bahwa motivasi berpengaruh terhadap semangat kerja karyawan, motivasi rekan kerja memiliki dampak besar dalam semangat kerja. Pada lingkungan kerja, karyawan akan merasa lebih semangat dan penuh dengan antusias melaksanakan pekerjaannya apabila atasan atau rekan kerjanya memberikan perhatian kepada karyawan itu sendiri sehingga pekerjannya akan diselesaikan dengan efektif dan efisien. Penelitian yang dilakukan oleh Kusuma (2015) di CV. F.A Management menyatakan bahwa motivasi memiliki pengaruh yang positif dan signifikan terhadap semangat kerja karyawannya, hasil ini juga sejalan dengan penelitian Mangkunegara \& Agustine (2016) bahwa variabel motivasi dapat menjelaskan variabel semangat kerja secara dominan. Dari beberapa penelitian terdahulu dapat ditarik kesimpulan bahwa dengan motivasi yang baik, maka semangat kerja karyawan akan baik pula, sehingga dapat dikatakan bahwa motivasi memiliki pengaruh yang signifikan dan positif terhadap semangat kerja karyawan. Dari uraian tersebut dapat dirumuskan hipotesis sebagai berikut : $\mathrm{H}_{1}$ : Motivasi berpengaruh positif dan signifikan terhadap semangat kerja karyawan

Komunikasi merupakan proses penyampaian atau pertukaran informasi dari satu orang ke orang lain yang mendorong individu untuk berpendapat, dan menukarkan pikirannya guna pencapaian suatu tujuan. Komunikasi yang baik sangat diperlukan bagi suatu organisasi dalam melaksanakan aktivitas manajemennya. Tanpa terjadinya komunikasi yang baik antar anggota organisasi, maka aktivitas organisasi tidak akan berjalan dengan efektif dan efisien. Komunikasi berkaitan dengan semangat kerja karyawan mengingat pentingnya komunikasi untuk menciptakan kinerja yang efektif. Penelitian yang dilakukan oleh Rochim (2011) menunjukkan bahwa komunikasi berpengaruh signifikan terhadap semangat kerja, hal ini berarti bahwa semakin intens dan interen komunikasi yang dilakukan maka akan semakin meningkatkan semangat kerja.

Begitu juga penelitian yang dilakukan oleh Yasa \& Wibawa (2015) juga menunjukkan hasil yang sama, yakni variabel komunikasi berpengaruh positif terhadap semangat kerja karyawan. Setianingsih (2010) menyatakan bahwa komunikasi berpengaruh pada tingkat semangat kerja karyawan. 
Welch (2011) menyatakan pada perusahaan umumya terjadi gap antara komunikasi internal karyawan dengan pimpinan atau manajemen perusahaan yang dipengaruhi oleh kondisi psikologi, peraturan, dan emosional karyawan. Gap yang terjadi akan mempengaruhi persepsi dan situasi kerja karyawan yang berpengaruh pada semangat kerjanya. Dari uraian tersebut dapat dirumuskan hipotesis sebagai berikut:

$\mathrm{H}_{2}$ : Komunikasi berpengaruh positif dan signifikan terhadap semangat kerja karyawan.

Lingkungan kerja fisik merupakan segala sesuatu yang berkaitan dengan tempat dimana karyawan melakukan aktivitasnya di sebuah organisasi. Lingkungan kerja fisik dapat mempengaruhi karyawan dalam melaksanakan tugas tugasnya di dalam organisasi. Ratnasari \& Sudjahjo (2017) mendukung hasil penlitian yang mengemukakan bahwa kepemimpinan transformasional dan lingkungan kerja berpengaruh positif terhadap semangat kerja. Widiantari \& Wasnury (2015) menyatakan bahwa lingkungan kerja fisik berpengaruh signifikan terhadap semangat kerja. Lingkungan kerja yang baik akan berdampak langsung terhadap hasil kerja karyawan. Hasanah (2016) menyatakan lingkungan kerja yang baik dan mendukung dapat meningkatkan semangat kerja karyawan, karena dengan adanya lingkungan serta fasilitas yang lengkap dan mendorong karyawan untuk melaksanakan tugasnya dengan baik, merasa senang dan tidak malas, sehingga memacu semangat kerja karyawan untuk melaksanakan pekerjaannya.

Penelitian Annisa (2015) meungkapkan bahwa dengan memperhatikan lingkungan kerja yang baik atau menciptakan kondisi kerja yang mampu memberikan motivasi untuk bekerja, maka akan membawa pengaruh terhadap kegairahan atau semangat kerja. Setiap perusahaan harus terus selalu berusaha untuk menciptakan dan memelihara lingkungan kerja yang baik agar karyawan dapat bekerja dan nyaman, tenteram dan stabil dengan yang diharapkan sehingga memungkinkan untuk dapat meningkatkan prestasi kerja yang baik dan dapat menghasilkan produk yang bagus (Ependi, 2014). Dari uraian tersebut dapat dirumuskan hipotesis sebagai berikut :

$\mathrm{H}_{3}$ : Lingkungan kerja fisik berpengaruh positif dan signifikan terhadap semangat kerja karyawan.

\section{METODE PENELITIAN}

Bentuk penelitian ini adalah penelitian asosiatif dengan pendekatan kuantitatif. Penelitian ini dilakukan di PT. Ayu Sari Pertiwi yang memiliki dua cabang yaitu berlokasi di Kota Denpasar yaitu di Jalan Imam Bonjol, Kecamatan Denpasar barat dan di Jalan Raya Sesetan, Kecamatan Denpasar Selatan. Objek dari penelitian ini adalah motivasi kerja karyawan, komunikasi karyawan, lingkungan kerja fisik karyawan, dan semangat kerja karyawan PT. Ayu sari Pertiwi, sedangkan subjeknya adalah karyawan PT. Ayu Sari Pertiwi.Variabel terikat dari penelitian ini adalah semangat kerja (Y). Yang termasuk variabel bebas dalam penelitian ini adalah motivasi (X1), komunikasi (X2), dan lingkungan kerja fisik (X3).

Semangat kerja merupakan keinginan dan kesungguhan seseorang dalam mengerjakan pekerjaannya meliputi perasaan seorang individu terhadap pekerjaan dan organisasinya. Semakin semangat seorang individu dalam mengerjakan 
pekerjaannya, maka akan semakin baik pula kinerja dari individu tersebut di dalam organisasinya.. Adapun beberapa hal yang penting untuk diperhatikan dalam menilai semangat kerja yaitu:

Tingkat kehadiran (Y1) tingkat kehadiran dalam hal ini adalah bagaimana karyawan memiliki aktivitas lain diluar pekerjaan yang tentu akan membuat mereka menyampingkan pekerjaannya. Indikator ini diukur dari persepsi responden mengenai semangat kerja yang dilihat dari absensi.

Pelaksanaan pekerjaan tepat waktu (Y2) merupakan ketepatan waktu pelaksanaan pekerjaan oleh karyawan. Indikator ini diukur dari presepsi responden mengenai kehadiran karyawan ditempat kerja dan pelaksanaan tugas dengan tepat waktu. Tidak meninggalkan tempat kerja pada waktu kerja (Y3) merupakan karyawan menunjukan kehadiran di tempat kerja sesuai dengan standar waktu yang ditetapkan. Indikator ini diukur dari persepsi responden mengenai kehadiran karyawan yang tidak meninggalkan tempat kerja saat jam kerja. Pelaksanaan pekerjaan sesuai instruksi atasan (Y4) dimana karyawan selalu melakukan pekerjaan sesuai perintah atasan. Indikator ini diukur dari persepsi responden mengenai tugas-tugas yang diberikan atasan.

Kepuasan terhadap pembagian tugas (Y5) adalah rasa puas karyawan dalam pembagian tugas yang diberikan oleh pimpinan. Indikator ini diukur dari persepsi responden mengenai kepuasan tugas yang diberikan.

Motivasi adalah suatu dorongan atau alasan yang menjadi dasar semangat seseorang untuk melakukan sesuatu sehingga menghasilkan tingkat kinerja yang optimal. Menurut Ardana dkk. (2014) menyatakan bahwa variabel motivasi diukur dengan indikator sebagai berikut:

Penempatan kerja yang tepat adalah perusahaan memberikan penempatan kerja yang sesuai dengan kemampuan karyawan sehingga karyawan termotivasi. Indikator ini diukur dari penilaian responden terhadap penempatan kerja yang sudah tepat.

Kondisi pekerjaan yang menyenangkan adalah perusahaan menciptakan kondisi pekerjaan yang menyenangkan untuk karyawan sehingga karyawan termotivasi. Indikator ini diukur dari penilaian responden terhadap kondisi pekerjaan yang dilakukan menyenangkan.

Penjagaan kesehatan adalah perusahaan memberikan penjagaan kesehatan yang layak dan sesuai dengan kebutuhan karyawan sehingga karyawan termotivasi. Indikator ini diukur dari penilaian responden terhadap penjagaan kesehatan.

Sistematika latihan adalah perusahaan memberikan pelatihan yang sistematik untuk meningkatkan kemampuan atau skill karyawan sehingga karyawan termotivasi. Indikator ini diukur dari penilaian responden terhadap sistematika latihan.

Komunikasi adalah pertukaran atau pemindahan informasi dari satu individu kepada individu lainnya guna menyampaikan sesuatu yang dianggap penting ataupun tidak penting dalam upaya mencapai tujuan. Indikator yang mengukur variabel komunikasi meliputi:

Pemahaman (X2.1) adalah kemampuan dalam mengartikan isi pesan secara cermat sesuai dengan apa yang komunikator maksudkan. Indikator ini diukur melalui persepsi responden tentang pemahaman segala informasi terkait pekerjaan 
Kesenangan (X2.2). Selain berfungsi sebagai penyampaian informasi, komunikasi juga menimbulkan perasaan dan suasana yang menyenangkan diantara pihak pihak yang bersangkutan. Dengan suasana yang menyenangkan maka akan timbul keharmonisan dan kenyamanan antar anggota organisasi. Indikator ini diukur melalui persepsi responden mengenai perasaan responden dalam menuangkan perasaan dan berpartisipasi dalam berpendapat.

Hubungan yang makin baik (X2.4), komunikasi yang efektif secara tidak langsung akan meningkatkan hubungan interpersonal dengan pihak pihak yang bersangkutan. Dengan hubungan interpersonal tersebut akan menciptakan hubungan baik antar pemimpin ataupun rekan kerja sehingga akan mendorong anggota organisasi untuk menyelesaikan tugasnya. Indikator ini diukur melalui persepsi responden tentang hubungan baik dengan bertegur sapa antar rekan kerja.

Pengaruh pada sikap (X2.3), komunikasi dapat mempengaruhi sikap dimana jika proses komunikasi nantinya menimbulkan perubahan sikap orang yang diajak berkomunikasi maka komunikasi tersebut dapat dikatakan efektif. Dengan komunikasi yang efektif maka para anggota organisasi dapat menyelesaikan tugasnya tepat waktu. Indikator ini diukur melalui persepsi responden mengenai penerimaan informasi yang baik sehingga dapat menyelesaikan tugas dengan tepat waktu.

Tindakan (X2.5), penyampaian informasi yang baik dalam proses komunikasi akan berpengaruh terhadap penerimaan informasi tersebut yang kemudian akan memicu terjadinya suatu tindakan. Dengan komunikasi yang baik di dalam sebuah organisasi seperti saling memberikan dorongan maka akan membantu anggota organisasi dalam bertindak. Indikator ini diukur melalui persepsi responden tentang kesesuaian pekerjaan dan informasi yang diberikan.

Lingkungan kerja fisik merupakan segala sesuatu yang berkaitan dengan tempat dimana karyawan melakukan aktivitasnya di sebuah organisasi yang memiliki pengaruh terhadap para karyawan melaksanakan tugas tugasnya di dalam organisasi. Terdapat beberapa indikator yang dapat mengukur lingkingan kerja fisik suatu organisasi:

Penerangan di tempat kerja (X3.1).Yang dimaksudkan penerangan di tempat kerja adalah cahaya. Cahaya memiliki banyak manfaat bagi kelangsungan aktivitas di dalam perusahaan. Indikator ini diukur melalui persepsi responden pada penerangan di tempat kerja yang sudah memadai.

Tingkat kebisingan (X3.2). Kebisingan merupakan aspek yang perlu diperhatikan pula, biasanya tempat yang bising akan mengganggu kenyamanan karyawan dalam melakukan aktivitasnya. Indikator ini diukur melalui persepsi responden pada tempat kerja yang jauh dari kebisingan.

Kebersihan lingkungan tempat bekerja (X3.3). Kebersihan di lingkungan tempat kerja merupakan suasana yang nyaman karena bebas dari kotoran dan sampah. Kebersihan ini harus di perhatikan, keadaan temat kerja yang kotor dan banyak debu akan membuat perasaan karyawan tidak senang dan dapat menimbulkan masalah keshatan bagi karyawan. Indikator ini diukur melalui persepsi responden pada kebersihan lingkungan di tempat kerja

Tata warna tempat kerja (X3.4). Pemilihan warna dalam tempat kerja berpengaruh terhadap kegairahan kerja karyawan yang menimbulkan semangat 
kerja yang tinggi. Warna ini juga akan ddipengaruhi oleh system penerangan di tempat kerja. Jika warna dan system penerangan dipadu padankan dengan baik maka akan menciptakan keindahan untuk pandangan karyawan. Indikator ini diukur melalui persepsi responden pada tata warna tempat kerja yang memberikan kenyamanan.

Ruang gerak yang mencukupi (X3.6). Ruang gerak para karyawan hendaknya diperhatikan karena akan menyangkut kepada keselamatan kerja karyawan dalam melakukan aktivitasnya. Indikator ini diukur dari persepsi responden mengenai ruang gerak di tempat kerja yang sudah mencukupi

Keadaan udara di tempat kerja (X3.5). Keadaan udara merupakan aspek penting bagi kelangsungan aktivitas di perusahaan. Keadaan udara juga akan mempengaruhi semangat kerja karyawan dimana apabila keadaan udara tidak baik seperti banyak polusi, maka karyawan tidak akan nyaman untuk bekerja. Indikator ini diukur melalui persepsi responden tentang keadaan udara yang bebas dari polusi.

Keamanan Lingkungan Kerja (X3.7). Keamanan lingkungan kerja adalah situasi dimana lingkungan kerja bebas dari ancaman fisik. Indikator ini diukur melalui persepsi responden tentang situasi lingkungan kerja yang aman.

Populasi dalam penelitian ini adalah seluruh karyawan PT. Ayu Sari Pertiwi yang berjumlah 56 Orang yang berada di dua cabang. Sampel pada penelitian ini adalah menggunakan jumlah karyawan sebanyak populasinya yaitu sebanyak 56 orang karena jumlah tersebut tidak begitu besar. Teknik pengambilan sampel dalam penelitian ini adalah penyempelan jenuh (saturated sampling), artinya seluruh anggota populasi dijadikan sampel penelitian.

Tabel 2.

Data Populasi dan Sampel PT. Ayu Sari Pertiwi

\begin{tabular}{|c|c|c|}
\hline No & Keterangan & Populasi \\
\hline 1 & Supervisor & 2 \\
\hline 2 & Administrasi & \\
\hline & $\begin{array}{ll}\text { - } & \text { Sekretaris } \\
\text { - } & \text { Bedahara }\end{array}$ & $\begin{array}{l}2 \\
3\end{array}$ \\
\hline 3 & Pengawas BBM & \\
\hline & - Operator & 45 \\
\hline & - Cleaning service & 4 \\
\hline Total & & 56 \\
\hline
\end{tabular}

Sumber: Data Primer, 2018

Data yang digunakan dalam penelitian ini adalah data primer yang berbentuk kuantitatif yang nantinya akan dikumpulkan menggunakan penyebaran kuisioner pada responden yang sudah ditentukan. Data sekunder yang digunakan dalam penelitian ini adalah buku-buku literature dan sejarah beserta struktur organisasi perusahaan.

Untuk memperoleh kebutuhan penelitian yang berupa data, data ini akan dikumpulkan melalui beberapa metode seperti wawancara dan penyebaran kuisioner. Wawancara, merupakan metode pengumpulan data dengan system tanya jawab secara langsung dengan karyawan PT. Ayu Sari Pertiwi. Kuisioner, yaitu metode penelitian dengan penyebaran daftar pertanyaan yang nantinya akan di 
jawab oleh responden dengan tujuan memperoleh data mengenai motivasi, komunikasi, lingkungan kerja fisik, dan semangat kerja karyawan PT. Ayu Sari Pertiwi Pernyataan dalam kuisioner diukur dengan menggunakan skala likert dengan skala $1-5$.

\section{HASIL DAN PEMBAHASAN}

PT. Ayu Sari Pertiwi merupakan perusahaan yang bergerak di bidang perdagangan yaitu penjualan bahan bakar kendaraan umum (SPBU) dengan nomor 541.801.2. PT. Ayu Sari Pertiwi memiliki 2 stasiun yang keduanya berlokasi di Kota Denpasar yaitu di Jalan Imam Bonjol, Kecamatan Denpasar barat dan di Jalan Raya Sesetan, Kecamatan Denpasar Selatan. PT. Ayu Sari Pertiwi berdiri pada tahun 2002.

Responden penelitian ini menggunakan seluruh karyawan PT. Ayu Sari Pertiwi dengan jumlah 56 orang. Uraian tentang karakteristik responden menyangkut empat aspek yaitu jenis kelamin, usia, pendidikan terakhir, dan lama bekerja.

Tabel 3.

Karakteristik Responden Berdasarkan Jenis Kelamin di Pt. Ayu Sari Pertiwi

\begin{tabular}{llll}
\hline No & Jenis Kelamin & Jumlah Orang & Persentase (\%) \\
\hline 1. & Laki-Laki & 51 & 91,07 \\
2. & Perempuan & 5 & 8,92 \\
& Total & $\mathbf{5 6}$ & $\mathbf{1 0 0}$ \\
\hline
\end{tabular}

Sumber : Data primer diolah, 2018.

Tabel 3. menunjukan bahwa sebagian besar responden adalah laki-laki sebanyak 51 orang dengan presentase 91,07 persen, sedangkan sisanya adalah perempuan sebanyak 5 orang dengan persentase 8,92 Persen. Artinya sebagian besar karyawan PT. Ayu Sari Pertiwi mempekerjakan tenaga laki-laki. Hal ini dikarenakan sebagian besar karyawan dibidangnya diperlukan tenaga laki-laki.

Tabel 4.

Karakteristik Responden Berdasarkan Usia di PT. Ayu Sari Pertiwi

\begin{tabular}{llll}
\hline No & Usia & Jumlah Orang & Persentase (\%) \\
\hline 1 & $21-30$ Tahun & 18 & 32,14 \\
2 & $31-40$ Tahun & 22 & 39,30 \\
3 & $41-50$ Tahun & 12 & 21,42 \\
4 & $51-60$ Tahun & 4 & 7,14 \\
& Total & $\mathbf{5 6}$ & $\mathbf{1 0 0}$ \\
\hline
\end{tabular}

Sumber : Data primer diolah, 2018.

Tabel 4. menunjukan bahwa sebagian besar responden berusia antara 31-40 tahun yaitu sebanyak 22 orang dengan persentase 39,30 sedanngkan untuk kelompok usia terendah yaitu pada usia 51-60 tahun sebanyak 4 orang dengan persentase 7,14. Hal ini menunjukan bahwa karyawan PT. Ayu Sari Pertiwi di dominasi oleh usia 31-40 tahun yang berada pada usia produktif. 
Tabel 5.

Karakteristik Responden Berdasarkan Pendidikan Terakhir

\begin{tabular}{llll}
\hline No & Pendidikan & Jumlah Orang & Persentase (\%) \\
\hline 1 & SMA & 46 & 82,14 \\
2 & DIPLOMA & 6 & 10,71 \\
3 & S1 & 4 & 7,14 \\
& Total & $\mathbf{5 6}$ & $\mathbf{1 0 0}$ \\
\hline
\end{tabular}

Sumber : Data primer diolah, 2018.

Tabel 5. menunjukan sebagian besar responden berdasarkan pendidikan terakhir adalah SMA sebanyak 46 orang dengan persentase sebesar 82,14 persen, sedangkan kelompok pendidikan terakhir paling rendah yang dimiliki oleh responden adalah S1 yaitu hanya 4 orang dengan persentase 7,14 persen. Hal ini menunjukan bahwa karyawan PT. Ayu Sari Pertiwi didominasi oleh pendidikan terakhir SMA. Hal ini dikarenakan standar pendidikan yang dibutuhkan adalah minimal SMA.

Tabel 6.

Karakteristik Responden Berdasarkan Lama Bekerja Karyawan

\begin{tabular}{cccc}
\hline No & Masa Kerja & Jumlah Orang & Persentase \%) \\
\hline 1 & 1-4 Tahun & 11 & 19.64 \\
2 & 5-8 Tahun & 13 & 23.22 \\
3 & 9-12 Tahun & 19 & 33,92 \\
4 & 13-16 Tahun & 13 & 23,22 \\
& Total & $\mathbf{5 6}$ & $\mathbf{1 0 0}$ \\
\hline
\end{tabular}

Sumber : Data primer diolah, 2018.

Tabel 6. menunjukan bahwa sebagian besar responden pada PT. Ayu Sari Pertiwi telah bekerja selama 9-12 tahun yaitu sebanyak 19 orang dengan persentase 33,92 persen. Karyawan yang bekerja paling sebentar adalah sebanyak 11 orang yaitu 1-4 tahun dengan persentase 19,64 persen. Hal ini menunjukan bahwa masa kerja karyawan PT. Ayu Sari pertiwi tergolong cukup lama.

Hasil uji validitas instrumen pada penelitian ini disajikan pada Tabel 7 yang menunjukan bahwa seluruh indikator dalam variabel semangat kerja, motivasi, komunikasi, dan lingkungan kerja fisik memiliki nilai Koefisien Korelasi yang lebih besar dari 0,3, jadi dapat disimpulkan bahwa butir-butir pernyataan dalam kuisioner penelitian tersebut dikatakan valid dan layak digunakan sebagai instrument penelitian.

Hasil uji reliabilitas instrumen penelitian disajikan pada Tabel 8 menunjukan bahwa seluruh instrumen penelitian memiliki koefisien Alpha Cronbach lebih besar daro 0,6. Sehingga dapat dikatakan bahwa seluruh variabel telah memenuhi syarat reliabilitas atau kehandalan sehingga dapat digunakan untuk melakukan penelitian.

Tabel 9. menunjukan bahwa deskripsi jawaban responden terhadap variabel semangat kerja karyawan sebesar 4,33 yang digolongkan dalam kinerja sangat tinggi. Dapat dilihat pernyataan dengan rata-rata paling tinggi yakni "Saya melaksanakan pekerjaan sesuai dengan instruksi atasan". Hal ini berarti bahwa 
karyawan sudah melaksanakan pekerjaan sesuai dengan instruksi atasan mereka. Sedangkan pernyataan dengan rata-rata paling rendah yakni "Tingkat kehadiran saya sudah baik". Hal ini berarti tingat kehadiran karyawan masih perlu ditingkatkan, yang sudah selalu hadir tepat waktu agar dipertahankan dan karyawan yang tingkat kehadirannya kurang bisa ditingkatkan.

Tabel 7.

Rekapitulasi Hasil Uji Validitas Instrumen Penelitian

\begin{tabular}{|c|c|c|c|}
\hline Variabel & Instrumen & Koefisien Korelasi & Keterangan \\
\hline \multirow{6}{*}{$\begin{array}{l}\text { Semangat Kerja } \\
\text { Karyawan (Y) }\end{array}$} & $\mathrm{Y}_{1}$ & 0,820 & Valid \\
\hline & $\mathrm{Y}_{2}$ & 0,753 & Valid \\
\hline & $Y_{3}$ & 0,863 & Valid \\
\hline & $\mathrm{Y}_{4}$ & 0,742 & Valid \\
\hline & $\mathrm{Y}_{5}$ & 0,813 & Valid \\
\hline & $\mathrm{X}_{1.1}$ & 0,928 & Valid \\
\hline \multirow{3}{*}{ Motivasi $\left(\mathrm{X}_{1}\right)$} & $\mathrm{X}_{1.2}$ & 0,835 & Valid \\
\hline & $\mathrm{X}_{1.3}$ & 0,881 & Valid \\
\hline & $\mathrm{X}_{1.4}$ & 0,948 & Valid \\
\hline \multirow{4}{*}{ Komunikasi $\left(\mathrm{X}_{2}\right)$} & $\mathrm{X}_{2.1}$ & 0,699 & Valid \\
\hline & $\mathrm{X}_{2.2}$ & 0,899 & Valid \\
\hline & $\mathrm{X}_{2.3}$ & 0,804 & Valid \\
\hline & $\mathrm{X}_{2.4}$ & 0,878 & Valid \\
\hline \multirow{8}{*}{$\begin{array}{l}\text { Lingkungan Kerja Fisik } \\
\qquad\left(\mathrm{X}_{3}\right)\end{array}$} & $\mathrm{X}_{2.5}$ & 0,875 & Valid \\
\hline & $\mathrm{X}_{3.1}$ & 0,853 & Valid \\
\hline & $\mathrm{X}_{3.2}$ & 0,749 & Valid \\
\hline & $\mathrm{X}_{3.3}$ & 0,812 & Valid \\
\hline & $\mathrm{X}_{3.4}$ & 0,730 & Valid \\
\hline & $\mathrm{X}_{3.5}$ & 0,803 & Valid \\
\hline & $\mathrm{X}_{3.6}$ & 0,733 & Valid \\
\hline & $\mathrm{X}_{3.7}$ & 0,624 & Valid \\
\hline
\end{tabular}

Sumber : Data diolah, (2018)

Tabel 8.

Rekapitulasi Hasil Uji Reliabilitas Instrumen Penelitian

\begin{tabular}{ccc}
\hline Variabel & Alpha Cronbach & Keterangan \\
\hline Semangat Kerja $(\mathrm{Y})$ & 0,840 & Reliabel \\
Motivasi $\left(\mathrm{X}_{1}\right)$ & 0,912 & Reliabel \\
Komunikasi $\left(\mathrm{X}_{2}\right)$ & 0,872 & Reliabel \\
Lingkungan Kerja Fisik $\left(\mathrm{X}_{3}\right)$ & 0,873 & Reliabel \\
\hline
\end{tabular}

Sumber: Data diolah, (2018)

Tabel 10. menunjukan bahwa deskripsi jawaban responden terhadap variabel motivasi sebesar 4,19 yang di golongkan dalam kriteria tinggi. Dapat dilihat pernyataan dengan rata-rata paling tinggi yakni "Penempatan kerja yang tepat memotivasi saya menjalankan tugas dengan baik". Hal ini berarti bahwa karyawan penempatan kerja mereka sudah tepat sehingga dapat memotivasi karyawan dalam menjalankan tugas dengan baik. Sedangkan pernyataan dengan rata-rata paling rendah yakni "Setiap karyawan diberi pelatihan yang sistematik untuk meningkatkan kemampuan atau skill dalam bekerja". Hal ini berarti setiap 
karyawan masih perlu diberikan pelatihan yang sistematik untuk meningkatkan kemampuan atau skill dalam bekerja.

Tabel 9.

Deskripsi Jawaban Responden Variabel Semangat Kerja Karyawan

\begin{tabular}{|c|c|c|c|c|c|c|c|c|}
\hline \multirow{2}{*}{$\begin{array}{c}\text { Pernyataan Semangat Kerja } \\
\text { Karyawan }\end{array}$} & \multicolumn{5}{|c|}{$\begin{array}{c}\text { Frekuensi Jawaban } \\
\text { Responden }\end{array}$} & \multirow{2}{*}{$\begin{array}{l}\text { Total } \\
\text { skor }\end{array}$} & \multirow[t]{2}{*}{$\begin{array}{l}\text { Rata- } \\
\text { rata }\end{array}$} & \multirow{2}{*}{ Kriteria } \\
\hline & 1 & 2 & 3 & 4 & 5 & & & \\
\hline Tingkat kehadiran saya sudah baik & 0 & 1 & 8 & 31 & 16 & 230 & 4.11 & Tinggi \\
\hline $\begin{array}{l}\text { Pekerjaan yang saya lakukan } \\
\text { selesai tepat waktu }\end{array}$ & 0 & 0 & 1 & 22 & 33 & 256 & 4.57 & $\begin{array}{l}\text { Sangat } \\
\text { Tinggi }\end{array}$ \\
\hline $\begin{array}{l}\text { Saya tidak meninggalkan } \\
\text { pekerjaan saat jam kerja }\end{array}$ & 0 & 0 & 10 & 27 & 19 & 233 & 4.16 & Tinggi \\
\hline $\begin{array}{l}\text { Saya melaksanakan pekerjaan } \\
\text { sesuai dengan instruksi atasan }\end{array}$ & 0 & 0 & 0 & 21 & 35 & 259 & 4.63 & $\begin{array}{l}\text { Sangat } \\
\text { Tinggi }\end{array}$ \\
\hline $\begin{array}{l}\text { Saya puas dengan pembagian kerja } \\
\text { yang dilakukan }\end{array}$ & 0 & 3 & 6 & 25 & 22 & 234 & 4.18 & Tinggi \\
\hline \multicolumn{7}{|c|}{ Rata-rata } & 4.33 & $\begin{array}{l}\text { Sangat } \\
\text { Tinggi }\end{array}$ \\
\hline
\end{tabular}

Sumber : Data diolah, (2018)

Tabel 10.

Deskripsi Jawaban Responden Mengenai Variabel Motivasi Karyawan

\begin{tabular}{|c|c|c|c|c|c|c|c|c|}
\hline \multirow[t]{2}{*}{ Pernyataan Motivasi } & \multicolumn{5}{|c|}{$\begin{array}{c}\text { Frekuensi Jawaban } \\
\text { Responden }\end{array}$} & \multirow{2}{*}{$\begin{array}{l}\text { Total } \\
\text { skor }\end{array}$} & \multirow{2}{*}{$\begin{array}{l}\text { Rata- } \\
\text { rata }\end{array}$} & \multirow{2}{*}{ Kriteria } \\
\hline & 1 & 2 & 3 & 4 & 5 & & & \\
\hline $\begin{array}{l}\text { Penempatan kerja yang tepat } \\
\text { memotivasi saya menjalankan } \\
\text { tugas dengan baik }\end{array}$ & 0 & 0 & 4 & 25 & 27 & 247 & 4.41 & $\begin{array}{l}\text { Sangat } \\
\text { Tinggi }\end{array}$ \\
\hline $\begin{array}{l}\text { Kondisi pekerjaan yang } \\
\text { menyenangkan memotivasi saya } \\
\text { untuk bekerja }\end{array}$ & 0 & 0 & 9 & 30 & 17 & 232 & 4.14 & Tinggi \\
\hline $\begin{array}{l}\text { Setiap karyawan diberi pelatihan } \\
\text { yang sistematik untuk } \\
\text { meningkatkan kemampuan atau } \\
\text { skill dalam bekerja }\end{array}$ & 0 & 4 & 7 & 28 & 17 & 226 & 4.04 & Tinggi \\
\hline $\begin{array}{l}\text { Setiap karyawan mendapatkan } \\
\text { penjagaan kesehatan sesuai dengan } \\
\text { kebutuhan }\end{array}$ & 0 & 3 & 8 & 22 & 23 & 233 & 4.16 & Tinggi \\
\hline \multicolumn{7}{|c|}{ Rata-rata } & 4,19 & Tinggi \\
\hline
\end{tabular}

Sumber : Data diolah, (2018)

Tabel 11. menunjukan bahwa deskripsi jawaban responden terhadap variabel komunikasi sebesar 4,34 yang digolongkan dalam kriteria sangat baik. Dapat dilihat pernyataan dengan rata-rata paling tinggi yakni "Saya memahami segala informasi terkait dengan pekerjaan". Hal ini berarti bahwa karyawan sudah memahami segala informasi terkait dengan pekerjaan mereka. Sedangkan pernyataan dengan rata-rata paling rendah yakni "Saya selalu bertegur sapa dengan rekan kerja". Hal ini berarti tegur sapa antar karyawan perlu ditingkatkan agar menciptakan keharmonisan dalam komunikasi. 
Tabel 11.

Deskripsi Jawaban Responden Mengenai Variabel Komunikasi

\begin{tabular}{|c|c|c|c|c|c|c|c|c|}
\hline \multirow[t]{2}{*}{ Pernyataan Komunikasi } & \multicolumn{5}{|c|}{$\begin{array}{l}\text { Frekuensi Jawaban } \\
\text { Responden }\end{array}$} & \multirow{2}{*}{$\begin{array}{l}\text { Total } \\
\text { skor }\end{array}$} & \multirow[t]{2}{*}{$\begin{array}{l}\text { Rata- } \\
\text { rata }\end{array}$} & \multirow{2}{*}{ Kriteria } \\
\hline & 1 & 2 & 3 & 4 & 5 & & & \\
\hline $\begin{array}{l}\text { Saya memahami segala informasi } \\
\text { terkait dengan pekerjaan. }\end{array}$ & 0 & 0 & 1 & 9 & 46 & 269 & 4,80 & $\begin{array}{l}\text { Sangat } \\
\text { Baik }\end{array}$ \\
\hline $\begin{array}{l}\text { Saya senang hati saya berpartisipasi } \\
\text { dalam bependapat. }\end{array}$ & 0 & 3 & 5 & 31 & 17 & 230 & 4.11 & Baik \\
\hline $\begin{array}{l}\text { Saya selalu bertegur sapa dengan } \\
\text { rekan kerja. }\end{array}$ & 0 & 5 & 0 & 40 & 11 & 225 & 4.02 & Baik \\
\hline $\begin{array}{l}\text { Saya menarima informasi mengenai } \\
\text { aktivitas pekerjaan dengan baik } \\
\text { sehingga pekerjaan selesai tepat waktu }\end{array}$ & 0 & 1 & 5 & 36 & 14 & 231 & 4.13 & Baik \\
\hline $\begin{array}{l}\text { Saya melakukan pekerjaan sesuai } \\
\text { informasi mengenai tugas-tugas yang } \\
\text { diberikan. }\end{array}$ & 0 & 0 & 0 & 20 & 36 & 260 & 4.64 & $\begin{array}{l}\text { Sangat } \\
\text { Baik }\end{array}$ \\
\hline \multicolumn{6}{|c|}{ Rata-rata } & & 4,34 & $\begin{array}{c}\text { Sangat } \\
\text { Baik }\end{array}$ \\
\hline
\end{tabular}

Sumber : Data diolah, (2018)

Tabel 12.

Deskripsi Jawaban Responden Mengenai Variabel Lingkungan Kerja Fisik

\begin{tabular}{|c|c|c|c|c|c|c|c|c|}
\hline \multirow[t]{2}{*}{$\begin{array}{c}\text { Pernyataan Lingkungan Kerja } \\
\text { Fisik }\end{array}$} & \multicolumn{5}{|c|}{$\begin{array}{l}\text { Frekuensi Jawaban } \\
\text { Responden }\end{array}$} & \multirow{2}{*}{$\begin{array}{l}\text { Total } \\
\text { skor }\end{array}$} & \multirow{2}{*}{$\begin{array}{l}\text { Rata- } \\
\text { rata }\end{array}$} & \multirow[t]{2}{*}{ Kriteria } \\
\hline & 1 & 2 & 3 & 4 & 5 & & & \\
\hline $\begin{array}{l}\text { Cahaya untuk penerangan sudah } \\
\text { memadai }\end{array}$ & 0 & 0 & 3 & 19 & 34 & 255 & 4.55 & $\begin{array}{c}\text { Sangat } \\
\text { Baik }\end{array}$ \\
\hline $\begin{array}{l}\text { Saya merasa suasana di tempat } \\
\text { kerja jauh dari kebisingan }\end{array}$ & 0 & 0 & 7 & 22 & 27 & 244 & 4.36 & $\begin{array}{l}\text { Sangat } \\
\text { Baik }\end{array}$ \\
\hline $\begin{array}{l}\text { Lingkungan tempat saya bekerja } \\
\text { nyaman dan bersih }\end{array}$ & 0 & 0 & 8 & 30 & 18 & 234 & 4.18 & Baik \\
\hline $\begin{array}{l}\text { Penempatan tata warna di tempat } \\
\text { kerja memberikan kenyamanan }\end{array}$ & 0 & 1 & 11 & 21 & 23 & 234 & 4.18 & Baik \\
\hline $\begin{array}{l}\text { Saya merasa memiliki ruang } \\
\text { gerak yang mencukupi }\end{array}$ & 0 & 1 & 10 & 29 & 16 & 228 & 4.07 & Baik \\
\hline $\begin{array}{l}\text { Saya merasa keadaan udara di } \\
\text { tempat kerja bebas polusi }\end{array}$ & 0 & 2 & 8 & 33 & 13 & 225 & 4.02 & Baik \\
\hline Situasi lingkungan kerja aman & 0 & 1 & 8 & 24 & 23 & 237 & 4.23 & $\begin{array}{c}\text { Sangat } \\
\text { Baik }\end{array}$ \\
\hline \multicolumn{7}{|c|}{ Rata-rata } & 4,23 & $\begin{array}{c}\text { Sangat } \\
\text { Baik }\end{array}$ \\
\hline
\end{tabular}

Sumber: Data diolah, (2018)

Tabel 12. menunjukan bahwa deskripsi jawaban responden terhadap variabel lingkungan kerja fisik sebesar 4,23 yang di golongkan dalam kriteria sangat baik. Dapat dilihat pernyataan dengan rata-rata paling tinggi yakni "Cahaya untuk penerangan sudah memadai". Hal ini berarti bahwa Cahaya untuk penerangan sudah memadai. Sedangkan pernyataan dengan rata-rata paling rendah yakni "Saya merasa keadaan udara di tempat kerja bebas polusi". Hal ini berarti karyawan merasa keadaan udara di tempat kerja tidak bersih dan tidak bebas dari polusi dan 
perusahaan perlu mengantisipasinya agar karyawan nyaman dengan lingkungan kerjanya.

Tabel 13.

Hasil Uji Analisis Regresi Linier Berganda

\begin{tabular}{|c|c|c|c|c|c|}
\hline \multirow[t]{2}{*}{ Model } & \multicolumn{2}{|c|}{$\begin{array}{l}\text { Unstandardized } \\
\text { Coefficients }\end{array}$} & \multirow{2}{*}{$\begin{array}{c}\begin{array}{c}\text { Standardized } \\
\text { Coefficients }\end{array} \\
\text { Beta } \\
\end{array}$} & \multirow[t]{2}{*}{$\mathbf{t}$} & \multirow[t]{2}{*}{ Sig. } \\
\hline & B & Std. Error & & & \\
\hline (constans) & 0,577 & 2,442 & & 0,236 & 0,814 \\
\hline Motivasi & 0,385 & 0,110 & 0,386 & 3,511 & 0,001 \\
\hline Komunikasi & 0,361 & 0,123 & 0,283 & 2,935 & 0,005 \\
\hline Lingkungan Kerja Fisik & 0,229 & 0,076 & 0,310 & 3,021 & 0,004 \\
\hline R Square & & & & & 0,660 \\
\hline Adjused R Square & & & & & 0,640 \\
\hline F Stastistik & & & & & 33,660 \\
\hline Signifikansi & & & & & 0,000 \\
\hline
\end{tabular}

Sumber : Data diolah, (2018)

Hasil analisis regresi linier berganda seperti yang ditunjukan pada Tabel 13. maka persamaan regresinya adalah sebagai berikut.

$\mathrm{Y}=0,577+0,386 \mathrm{X} 1+0,283 \mathrm{X} 2+0,310 \mathrm{X} 3$.

Persamaan regresi linear berganda tersebut menunjukan arah masing-masing variabel bebas terhadap variabel terikatnya. Persamaan regresi linear berganda tersebut dapat diuraikan sebagai berikut.

Nilai konstanta diasumsikan bahwa tanpa ditambahkan variabel Motivasi, komunikasi dan lingkungan kerja fisik maka nilai semangat kerja akan tetap ada sebesar 0,577 .

Nilai koefisien beta $\mathrm{X}_{1}$ (Motivasi) bernilai positif 0,386 yang berarti apabila motivasi mengalami peningkatan dengan asumsi komunikasi dan lingkungan kerja fisik dianggap tetap maka semangat kerja akan meningkat sebesar 0,386.

Nilai koefisien beta $\mathrm{X}_{2}$ (komunikasi) bernilai positif 0,283 yang berarti apabila komunikasi mengalami peningkatan dengan asumsi motivasi dan lingkungan kerja fisik dianggap tetap maka semangat kerja akan meningkat sebesar 0,283 .

Nilai koefisien beta $\mathrm{X}_{3}$ (lingkungan kerja fisik) bernilai positif 0,310 yang berarti apabila lingkungan kerja fisik mengalami peningkatan dengan asumsi motivasi dan komunikasi dianggap tetap maka semangat kerja akan meningkat sebesar 0,310 .

Tabel 14.

Hasil Uji Normalitas

\begin{tabular}{cc}
\hline & Unstandardized Residual \\
\hline $\mathbf{N}$ & 56 \\
Kolmogorov-Smirnov Z & 0,058 \\
Asymp. Sig. (2-tailed) & 0,200 \\
\hline
\end{tabular}

Sumber : Data diolah, (2018) 
Tabel 14. dapat dilihat bahwa nilai Kolmogorov Sminarnov (K-S) sebesar 0,058, sedangkan nilai Asymp. Sig. (2-tailed) sebesar 0,200. Hasil tersebut mengindikasikan bahwa model persamaan regresi tersebut berdistribusi normal karena nilai Asymp. Sig. (2-tailed) lebih besar dari nilai alpha 0,05.

Tabel 15.

Hasil Uji Multikolinearitas

\begin{tabular}{lcc}
\hline \multirow{2}{*}{ Model } & \multicolumn{2}{c}{ Colinearity Statistic } \\
\cline { 2 - 3 } & Tolerance & VIF \\
\hline Motivasi $\left(\mathrm{X}_{1}\right)$ & 0,542 & 1,846 \\
Komunikasi $\left(\mathrm{X}_{2}\right)$ & 0,702 & 1,425 \\
Lingkungan Kerja Fisik $\left(\mathrm{X}_{3}\right)$ & 0,620 & 1,612 \\
\hline
\end{tabular}

Sumber: Data diolah, (2018)

Tabel 15. dapat dilihat bahwa nilai tolerance dan VIF dari semua variabel menunjukkan nilai tolerance untuk setiap variabel lebih besar dari $10 \%$ dan nilai VIF lebih kecil dari 10 yang berarti model persamaan regresi bebas dari multikolinearitas.

Tabel 16.

Hasil Uji Heteroskedastisitas

\begin{tabular}{lrrrrr}
\hline \multirow{2}{*}{ Model } & \multicolumn{2}{c}{$\begin{array}{c}\text { Unstandardized } \\
\text { Coefficients }\end{array}$} & $\begin{array}{c}\text { Standardized } \\
\text { Coefficients }\end{array}$ & T & Sig. \\
\cline { 2 - 4 } & \multicolumn{1}{c}{ B } & Std. Error & Beta & & \\
\hline (Constant) & 1,582 & 1,526 & & 1,036 & 0,305 \\
Motivasi & $-0,036$ & 0,069 & $-0,099$ & $-0,530$ & 0,598 \\
Komunikasi & 0,034 & 0,077 & 0,072 & 0,439 & 0,662 \\
Lingkungan Kerja Fisik & $-0,018$ & 0,047 & $-0,068$ & $-0,387$ & 0,701 \\
\hline
\end{tabular}

Sumber: Data diolah, (2018)

Tabel 16. dapat dilihat bahwa nilai signifikansi dari variabel variabel Motivasi sebesar 0,598, variabel komunikasi sebesar 0,662 dan variabel lingkungan kerja fisik sebesar 0,701. Nilai tersebut lebih besar dari 0,05 yang berarti tidak terdapat pengaruh antara variabel bebas terhadap absolute residual. Dengan demikian, model yang dibuat tidak mengandung gejala heteroskedastisitas.

Tabel 17.

Hasil Analisis Koefisien Determinasi $\left(\mathbf{R}^{2}\right)$

\begin{tabular}{cccc}
\hline $\mathbf{R}$ & R Square & Adjusted R Square & Std. Error of the Estimate \\
\hline 0,812 & 0,660 & 0,640 & 1,557 \\
\hline
\end{tabular}

Sumber: Data diolah, (2018) 
Tabel 17. menunjukkan besarnya pengaruh variabel bebas terhadap variabel terikat yang ditunjukkan oleh nilai determinasi total (Adjused $R$ Square) sebesar 0,640 mempunyai arti bahwa sebesar $64 \%$ variasi semangat kerja karyawan dipengaruhi oleh variasi Motivasi, komunikasi dan lingkungan kerja fisik sedangkan sisanya sebesar 36\% dijelaskan oleh faktor lain yang tidak dimasukkan ke dalam model.

Tabel 18.

Hasil Uji Kelayakan Model (Uji Statistik F)

\begin{tabular}{rrrrrrr}
\hline & Model & Sum of Squares & Df & Mean Square & F & Sig. \\
\hline \multirow{3}{*}{$\mathbf{1}$} & Regression & 244,798 & 3 & 81,599 & 33,660 & $0,000^{\mathrm{b}}$ \\
& Residual & 126,059 & 52 & 2,424 & & \\
& Total & 370,857 & 55 & & & \\
\hline
\end{tabular}

Sumber : Data diolah, (2018)

Tabel 18. menunjukan nilai sig. $0,000<0,05$. Maka $\mathrm{H}_{0}$ ditolak pada taraf nyata 0,05 Sehingga $\mathrm{H}_{0}$ ditolak, dengan kata lain pada kelompok yang diuji memiliki perbedaan nyata (signifikansi), berarti bahwa variabel bebas yaitu motivasi $\left(\mathrm{X}_{1}\right)$, komunikasi $\left(\mathrm{X}_{2}\right)$, dan lingkungan kerja fisik $\left(\mathrm{X}_{3}\right)$ berpengaruh signifikan secara simultan terhadap variabel terikat yaitu semangat kerja karyawan (Y). Serta model layak untuk digunakan.

Berdasarkan hasil regresi linear berganda diketahui bahwa nilai koefisien beta variabel motivasi bernilai positif yakni 0,386 dengan signifikan untuk motivasi yakni 0,001 kurang dari $0,05(0,001<0,05)$, dengan nilai t hitung 3,511 yang dibandingkan dengan nilai $t$ tabel dengan derajat kebebasan (degree of freedom) $\mathrm{N}$ $-\mathrm{k}=56-4=52$ dan signifikan 0,05. Diperoleh nilai t tabel sebesar 2,007 sehingga nilai $t$-hitung $>t$-tabel $(3,511>2,007)$. Dengan demikian, $\mathrm{H}_{1}$ diterima. Sehingga Motivasi berpengaruh positif dan signifikan terhadap semangat kerja karyawan.

Berdasarkan hasil regresi linear berganda diketahui bahwa nilai koefisien beta variabel komunikasi bernilai positif yakni 0,283 dengan signifikan untuk motivasi yakni 0,005 kurang dari $0,05(0,005<0,05)$, dengan nilai t hitung 2,935 yang dibandingkan dengan nilai t tabel dengan derajat kebebasan (degree offreedom) $\mathrm{N}$ $-\mathrm{k}=56-4=52$ dan signifikan 0,05. Diperoleh nilai t tabel sebesar 2,007 sehingga nilai $t$-hitung $>t$-tabel $(2,935>2,007)$. Dengan demikian, $\mathrm{H}_{2}$ diterima. Sehingga komunikasi berpengaruh positif dan signifikan terhadap semangat kerja karyawan.

Berdasarkan hasil regresi linear berganda diketahui bahwa nilai koefisien beta variabel Lingkungan Kerja Fisik bernilai positif yakni 0,310 dengan signifikan untuk motivasi yakni 0,004 kurang dari $0,05(0,004<0,05)$, dengan nilai t hitung 3,021 yang dibandingkan dengan nilai t tabel dengan derajat kebebasan (degree of freedom) $\mathrm{N}-\mathrm{k}=56-4=52$ dan signifikan 0,05 . Diperoleh nilai t tabel sebesar 2,007 sehingga nilai $t$-hitung $>t$-tabel $(3,021>2,007)$. Dengan demikian, $\mathrm{H}_{3}$ diterima. Sehingga Lingkungan Kerja Fisik berpengaruh positif dan signifikan terhadap semangat kerja karyawan. 
Hasil pengujian hipotesis terbukti bahwa motivasi berpengaruh positif dan signifikan terhadap semangat kerja karyawan. Yang berarti apabila motivasi semakin tinggi maka semangat kerja karyawan PT. Ayu Sari Pertiwi akan meningkat dan sebaliknya, jika tingkat motivasi karyawan rendah maka semangat kerja yang dimiliki karyawan di PT. Ayu Sari Pertiwi akan menurun.

Hasil penelitian ini sesuai dengan hipotesis satu $\left(\mathrm{H}_{1}\right)$ yang diajukan dan sesuai dengan hasil penelitian yang dilakukan oleh Omolo (2015), Hasan \& Subhani (2011), Liu (2015), Elqadri, et al. (2015), Gîlmeanu (2015), Mangkunegara \& Agustine (2016), Yahyo \& Dewi (2013) dan Renah \& Setyadi (2014) yang menyatakan bahwa motivasi kerja berpengaruh positif terhadap semangat kerja. Artinya, pemberian motivasi kerja yang baik oleh perusahaan mampu meningkatkan semangat kerja karyawan untuk bekerja lebih baik.

Dapat dilihat pernyataan pada deskripsi jabwaban responden dengan rata-rata paling tinggi yakni "Saya melaksanakan pekerjaan sesuai dengan instruksi atasan". Hal ini berarti bahwa karyawan sudah melaksanakan pekerjaan sesuai dengan instruksi atasan mereka. Sedangkan pernyataan dengan rata-rata paling rendah yakni "Tingkat kehadiran saya sudah baik". Hal ini berarti tingat kehadiran karyawan masih perlu ditingkatkan, yang sudah selalu hadir tepat waktu agar dipertahankan dan karyawan yang tingkat kehadirannya kurang bisa ditingkatkan.

Hasil pengujian hipotesis terbukti bahwa lingkungan kerja fisik berpengaruh positif dan signifikan terhadap semangat kerja karyawan. Yang berarti semakin baik kondisi lingkungan kerja maka semangat kerja karyawan di PT. Ayu Sari Pertiwi akan meningkat dan sebaliknya, jika kondisi lingkungan kerja fisik kurang baik maka semangat yang dimiliki karyawan di PT. Ayu Sari Pertiwi akan menurun.

Hasil penelitian ini sesuai dengan hipotesis tiga $\left(\mathrm{H}_{1}\right)$ yang diajukan dan sesuai dengan hasil penelitian yang dilakukan oleh Anwar (2013) mengatakan bahwa lingkungan kerja berpengaruh positif terhadap semangat kerja pegawai. Mc Guire dan Riyanto et al. (2017) menyatakan pula bahwa terdapat hubungan yang signifikan antara lingkungan kerja dengan semangat kerja karyawan.

Dapat dilihat pernyataan dengan rata-rata paling tinggi yakni "Cahaya untuk penerangan sudah memadai". Hal ini berarti bahwa Cahaya untuk penerangan sudah memadai. Sedangkan pernyataan dengan rata-rata paling rendah yakni "Saya merasa keadaan udara di tempat kerja bebas polusi". Hal ini berarti karyawan merasa keadaan udara di tempat kerja tidak bersih dan tidak bebas dari polusi dan perusahaan perlu mengantisipasinya agar karyawan nyaman dengan lingkungan kerjanya.

Hasil pengujian hipotesis penelitian terbukti bahwa komunikasi berpengaruh positif dan signifikan terhadap semangat kerja karyawan. Hal ini berarti apabila komunikasi semakin tinggi maka semangat kerja karyawan PT. Ayu Sari Pertiwi akan meningkat dan sebaliknya, jika komunikasi karyawan rendah maka semangat kerja yang dimiliki karyawan di PT. Ayu Sari Pertiwi akan menurun. Hasil penelitian ini sesuai dengan hipotesis dua $\left(\mathrm{H}_{1}\right)$ yang diajukan dan sesuai dengan hasil penelitian yang dilakukan oleh Yasa \& Wibawa (2015), Mudasir (2014) dan Karademir et al. (2014) yang berisi komunikasi berpengaruh signifikan terhadap semangat kerja karyawan. 
Dapat dilihat pernyataan dengan rata-rata paling tinggi yakni "Saya memahami segala informasi terkait dengan pekerjaan". Hal ini berarti bahwa karyawan sudah memahami segala informasi terkait dengan pekerjaan mereka. Sedangkan pernyataan dengan rata-rata paling rendah yakni "Saya selalu bertegur sapa dengan rekan kerja". Hal ini berarti tegur sapa antar karyawan perlu ditingkatkan agar menciptakan keharmonisan dalam komunikasi.

Hasil penelitian ini memiliki implikasi teoritis dan praktis. Secara teoritis penelitian ini menunjukan bahwa motivasi, komunikasi dan lingkungan kerja fisik berpengaruh positif dan signifikan terhadap semangat kerja karyawan. Dengan demikian, hasil penelitian ini memberikan dukungan empiris dan dapat dinyatakan memperkuat hasil-hasil studi terdahulu. Secara praktis dari penelitian ini diharapkan bagi pemimpin PT. Ayu Sari Pertiwi dapat lebih memperhatikan semangat kerja karyawan yang dipengaruhi oleh motivasi, komunikasi, dan lingkungan kerja fisik ini yang ditunjukkan oleh koefisien determinasi sebesar 64,0 persen, namun diperhatikan juga faktor lain yang mempengaruhi semangat kerja karyawan.

\section{SIMPULAN}

Berdasarkan hasil analisis penelitian maka simpulan dari penelitian ini adalah sebagai berikut: 1) Motivasi berpengaruh positif dan signifikan terhadap semangat kerja karyawan. Hal ini berarti apabila jika motivasi semakin meningkat maka semangat kerja karyawan semakin meningkat pula. 2) Lingkungan kerja fisik berpengaruh positif dan signifikan terhadap semangat kerja karyawan. Hal ini berarti apabila jika lingkungan kerja semakin meningkat maka semangat kerja karyawan semakin meningkat pula. 3) Komunikasi berpengaruh positif dan signifikan terhadap semangat kerja karyawan. Hal ini berarti apabila jika komunikasi yang diberikan meningkat maka semangat kerja karyawan semakin meningkat pula.

Saran yang dapat diberikan berdasarkan hasil analisis dan pembahasan adalah pihak perusahaan harus lebih memperhatikan motivasi yang diberikan untuk para karyawannya, dimana karyawan masih perlu diberikan pelatihan yang sistematik untuk meningkatkan kemampuan atau skill dalam bekerja. Dengan hal tersebut karyawan akan lebih terarah lagi dalam melakukan pekerjaannya dan bersemangat dalam menjalankan tugas serta tanggung jawabnya. Pihak perusahaan harus lebih memperhatikan polusi udara yang ada di lingkungan kerja karyawannya karena hal tersebut bisa membuat karyawan merasa tidak nyaman dan mengganggu kesehatan karyawan. Perusahaan dapat memberikan fasilitas tertentu untuk membuat karyawan merasa nyaman dalam bekerja sehingga meningkatkan semangat kerjanya.

Pimpinan dan antar sesama karyawan harus lebih sering saling bertegur sapa agar dapat menciptakan suasana yang harmonis dari atasan maupun bawahannya mengingat pentingnya untuk saling menjaga komunikasi agar tidak menjadi suatu hambatan yang nantinya dapat mempengaruhi semangat kerja karyawan. 


\section{REFERENSI}

Aborisade, R., \& Obioha, E. E. (2009). The Role Motivation In Enhancing Job Morale In Nigeria Industies : A Case Study Of Energy Foods Company Limited Ibadan. Internasional Journal of Economic, 19(2), 149-162.

Ahmed, I., M.M, N., Iqbal, N., Ali, I., Zeeshan, S., \& Usman, A. (2010). Effects of Motivational Factors on Employees Job Satifaction A Case Study Of University Of The Punjab, Pakistan. International Journal of Business and Management, 5(3), 70-80.

Alwi, M., Syalvana, A., \& Risnashari. (2016). Pengaruh Semangat Kerja Pegawai Terhadap Keefektifan Organisasi Program Belajar Jaraj Jauh Universitas Terbuka Makasar. Jurnal Analisis Dan Pelayanan Publik, 2(1), 1-20.

Annisa, N. (2015). Pengaruh Lingkungan Kerja Terhadap Semangat Kerja Pegawai Di Kantor Kelurahan Air Putih Samarinda. Ejournal Administrasi Negara, 3(5), 1452-1463.

Ardana, I. K., Mujiati, N. wayan, \& Utama, I. W. M. (2014). Manajemen Sumber Daya Manusia (Edisi Pert). Yogyakarta: Graha Ilmu.

Elqadri, Z. M., Wardoyo, D. T. W., \& Priyono. (2015). The Influence Of Motivation And Discipline Work Against Employee Work Productivity Tona'an Markets. Review Of European Studies, 7(12), 1918-7173.

Ependi, Z. (2014). Pengaruh Kompensasi dan Lingkungan kerja Terhadap Semangat Kerja Karyawan Pada Perusahaan Daerah Air Minum (PDAM) Tirta Kampar Bangkinang Kota. Universitas Islam Negeri Sultan Syarif Kasim Riau.

Gîlmeanu, M. R. (2015). Theoretical considerations on motivation at the work place, job satisfaction and individual performance. Valahian Journal of Economic Studies, 6(3), 69-80.

Hasan, S. A., \& Subhani, M. . (2011). Can co-workers motivational efforts pave the way for morale and job commitment for employees. Journal of Economics, Finance and Administrative Sciences, 4(3), 168-171.

Hasanah, R. (2016). Pengaruh Lingkungan Kerja Terhadap Semangat Kerja Karyawan Bagian Service Pada PT. United Tracktor Tbk Pekanbaru. Jom Fisip, 3(1), 1-12.

Irawan, T. A., Hidayat, H., \& Muninghar, M. (2018). Pengaruh Gaya Kepemimpinan Transformasional Dan Motivasi Kerja Terhadap Kinerja Melalui Semangat Kerja Pegawai Pada Kantor Pemerintah Kabupaten Bojonegoro. MAP (Jurnal Manajemen Dan Adminstrasi Publik), 1(3), 370-383.

Karademir, T., Karakaya, Y. E., \& Sirin, Y. (2014). Physical Education Teachers' Preceptions of Organizational Culture and Communications in 
Educational Institutions. Journal of Physical Educarion and Sport, 14(4), 637-642.

Kusuma, I. K. A. Y. (2015). Pengaruh Kepemimpinan, Lingkungan Kerja Fisik, Dan Kompensasi Pada Kinerja Karyawan Ud.Terus Di Bali. Jurnal Manajemen, Strategi Bisnis Dan Kewirausahaan, 9(2), 12-23.

Liu, P. (2015). Motivating Teachers' Commitment To Change Through Transformational School Leadership In Chinese Urban Upper Secondary Schools. Journal of Educational Administration, 53(6), 735 - 754.

Mangkunegara, A. P., \& Agustine, R. (2016). Effect Of Training, Motivation And Work Environment On Physicians' Performance. Academic Journal Of Interdisciplinary Studies, 5(1), 345-350.

Mudasir. (2014). The Effect Of Leadership, Communication, And Discipline Of The Population Administration Services In Palembang. Scientific Research Journal (Scirj), 2(8), 2201-2796.

Nitisemito, A. . (2008). Manajemen Personalia. Jakarta: Adisi Indonesia.

Omolo, P. A. (2015). Effect of motivation on employee performance of commercial banks in Kenya: A case study of Kenya Commercial Bank in Migori County. International Journal of Human Resource Studies, 5(2), 87-103.

Ratnasari, S. L., \& Sudjahjo, G. (2017). Pengaruh Kepemimpinan Transformasional dan Lingkungan Kerja Terhadap semangat Kerja Tenaga Kependidikan. Jurnal Inspirasi Bisnis Dan Manajemen, 1(2), 99112.

Renah, A., \& Setyadi, D. (2014). The Influence Of Organizational Culture, Working Environment And Educational Training On Motivation And Performance Of Government Employees At West Kutai Regency East Kalimantan. European Journal Of Business And Management, 6(10), 119.

Riyanto, S., Sutrisno, A., \& Ali, H. (2017). The Impact Of Working Motivation And Working Environment On Employees Performance In Indonesia Stock Exchange. International Review Of Management And Marketing, 7(3), 342-348.

Rochim, N. (2011). Analysis of The Influence of Communication Leadership and Work Environment for Teachers and Staff Morale. Dinamika Manajemen, 1(2), 103-113.

Setianingsih. (2010). Pengaruh Kompensasi Dan Komunikai Internal Trehadap Semangat Kerja Karyawan Pada Koperasi "SAF" Desa Rujon Lor Kecamatan Pujon, Malang. Jurnal Eekslusif, 3(1), 1-23.

Tella, A. (2007). Work Motivation, Job Satisfaction, and Organisational 
Commitment Of Library Personnel In Academic and Research Libraries in Oyo State, Nigeria. International Journal of Economic, 1(2), 1-15.

Utamajaya, I. D. G. A. P., \& Sriathi, A. A. A. (2015). Pengaruh Motivasi, Komunikasi, Serta Lingkungan Kerja Fisik Terhadap Semangat Kerja Karyawan Pada Fuji Jaya Motor Gianyar. E-Jurnal Manajemen Unud, $4(6), 1504-1524$.

Welch, M. (2011). The evolution of the employee engagement concept: communication implications, Corporate Communications. An International Journal, 16(4), 328-346.

Widiantari, D. S. N., \& Wasnury, R. (2015). Pengaruh Kepemimpinan dan Lingkungan Kerja Terhadap Semangat Kerja Pegawai Puskesmas Sidomulyo Pekanbaru. Jom FEKON, 2(1), 1-12.

Yahyo, H. D., \& Dewi, R. S. (2013). Pengaruh Motivasi, Lingkungan Kerja, dan Kompensasi Terhadap Kinerja Karyawan melalui Semangat Kerja Karyawan. Diponegoro Journal of Social and Politic, 2(3), 1-2.

Yasa, I. K. M. S., \& Wibawa, I. M. A. (2015). Pengaruh Kompensasi finansial, Komunikasi, dan Lingkungan Kerja Fisik Terhadap semangat Kerja Karyawan. E-Journal Management Unud, 4(3), 750-763. 